\title{
POLITICAL SCIENCES
}

\section{POLITICAL OR POLITICAL CONTEXT OF THE LANGUAGE POLICY MODEL: TO DEFINITION}

\section{Svitlana Savoyska ${ }^{1}$}

DOI: https://doi.org/10.30525/978-9934-588-11-2_59

The concept of «political» is based on a phenomenon such as politics, which is an institutional constructive component of the construction of the historical-political structure of the model of language policy, which must be associated with the legal culture and order, which is the greatest good in the context of intense political struggle between different communities and their cultures. On this basis, the term «political» [politicos] should be understood as cautious, careful, diplomatic, concerning actions, actions, behaviors, etc. [2, p. 485].

The model of language policy in formation and development goes through a certain historical and political path, which is often governed by those who have a different understanding of the culture, language, history, customs, traditions of Ukrainians, and - more opportunities, authority, power, a powerful ideological and military force to control the linguistic and political space of the Ukrainian state. That is, the term «political» comes from the concept of «politics» [French. politique] and is closely associated with it $[5, \mathrm{p}$. 506], including language policy. The dominance of one state over the linguistic and political space of another and the management of its community on the basis of another's language and culture implies, in A. Vysotsky's right mind, «the use of linguistic technologies, which are effective tools for regulating linguistic-political relations that rely on linguistic mechanisms, functioning in conversations and negotiations, in propaganda battles to gain and exercise power. Using technology, language is manipulated as a symbol for achieving unity and loyalty to the new government, forming its legitimacy and ideological guidelines...» [1, p. 138].

Politics, among other things, is the art of the possible, as well as the object and object of the study of political science. It also concerns political regime, political activity and participation, the pursuit of language policy, the formation or development of a model of language policy, and so on. Politics [from gr. the words political - public or public affairs], which arises together with the emergence of the state and coexists with it, is a concept which means relations, views (concepts) and actions in connection with a particular state system; the sphere of activity, the focus of which is the relations and actions related to the conquest, retention and use of state

\footnotetext{
${ }^{1}$ Interregional Academy of Personnel Management, Ukraine ORCID: https://orcid.org/0000-0002-5728-0686
} 
power, which is the most important category of policy and content of its activity, which is aimed at regulating linguistic-political conflicts with the help of national interests and values. In particular, M. A. Obushnyi, A. A. Kovalenko and O. I. Tkach are understood as politics of domination and subjugation between the state and its citizens, competition and direct struggle of citizens, social groups over the use of state power in their own interests, interaction and confrontation of public forces in connection with specific actions of state bodies [3, p. 477].

The political science context of the language policy model is a piece of text completed in a meaningful and essential way, which is formed on the basis of evolutionary-destructive, bio-geodeterministic, institutional and other. methodologies linking its parts (contexts) within the whole (model) as a whole organism, which is in continuous interaction in the conditions of periodic statelessness of a certain people, in particular Ukrainian. The term «political» comes from the category of «political science», which, in contrast to the concept of «politics», is a science that studies: politics, its laws of functioning and development of the political sphere of society and political life in the context of power and authority; socio-philosophical and ideological-theoretical foundations, language policy and its models, political relations, political systems, political culture, political institutions, political process, political behavior, etc. Political science is a science that studies the political world, the sphere of human activity, and so on [4, p. 606].

Therefore, based on the above, political science is aimed at analysis, expert evaluation and conclusions. It encourages the study of political systems and regimes, mechanisms for the struggle for power, methods and methods of subordination and enslavement of citizens. Therefore, the study of the political science context of the language policy model should be based not on the political context originating from the concept of «politics» but on the political science, which is based on political science as a science, which studies politics as a sphere of society, its processes and phenomena, and - language policy as an institution, the subject of which is the pattern of its formation and development. Institutions such as the state, its structure, power, its relations, political parties, public and political organizations, movements, their activities, political consciousness of political subjects, their political culture, interest, constructively or destructively influence the formation of the political model of the language policy. interaction, self-awareness, behavior, ideology, etc. Given the history of the formation and development of the Ukrainian state, the political science context of the language policy model is effectively developing and developing at the stages of state independence and independence. During the occupation of the territory of Ukraine by other states, the national context of the language policy model was hampered. In such a case, the model of language policy of the occupation power was imposed on the Ukrainian people by violent methods, which was formed on the basis of language and culture alien to Ukrainians. This happened in the days of domination in Ukraine of Polish, Russian, Romanian, Hungarian and others. regimes that imposed on ethnic Ukrainians their own model of language policy. As a result, the Ukrainian people have inherited a major linguistic and political problem that is part of a shattered identity, political culture, spirituality, unformed national consciousness 
and idea. All these and more. the components of the language-political problem are splitting the Ukrainian politicians and the Ukrainian people as a whole by their linguistic-political and regional characteristics.

\section{References:}

1. Vysotsky, O. (2019). Theoretical and methodological dimensions of language policy. Philosophical, philosophical and cultural contexts of continuous education: materials of the international scientific-practical conference. April 12-13, DANO DOR. Science. ed. OE Vysotska. Dnipro: SPD «Hunter», pp. 138-140.

2. New vocabulary dictionary: approx (2008). $40000 \mathrm{ff}$. and word combinations. L. I. Shevchenko, O. I. Nick, O. I. Khomyak, A. A. Demianyuk; Edited L. I. Shevchenko. Kyiv : ARIY, 672 p.

3. Obushnyi, M. I. (2004). Political Science: Handbook. M. I. Obushnyi, A. A.Kovalenko, O. I. Tkach; Edited M. I. Obushny. Kyiv : Trust, 599 p.

4. Political Science Dictionary: Nav. tool. for students. higher. teach. closed (2005). Edited M. F. Golovaty and O. V. Antonyuk. Kyiv : MAUP, 792 p.

5. Skopenko, O. I., Tsymbalyuk, T. V. (2008). Modern dictionary-minimum of foreign words. Kiev : Dovira Publishing House, 798 p. 